\title{
Equalizing Expenditures in Congressional Campaigns: A Proposal
}

\author{
RICHARD L. HALL
}

A MONG WASHINGTON ACTIVISTS, the prospects for effective campaign finance reform have often cycled between cautious optimism and deep disillusionment. The general public has been more steadfastly cynical, their democratic sensibilities deadened by the ever more remarkable sums of money raised and spent by private interests on public campaigns with each new election. ${ }^{1}$ Surely, all that money must be buying elections, bribing legislators, or biasing legislation in some way-purchases that "special interests" but not rank and file voters can afford. Viewed in this light, the hallowed democratic principle of "one person, one vote" loses its normative luster.

The Bipartisan Campaign Reform Act of 2002 (BCRA) represented a significant countermeasure to the widely criticized connection between private money and political influence. Among its important provisions, the bill prohibited the sometimes gargantuan soft money contributions to political parties; it prohibited corporate and labor union funding of "electioneering communications" and otherwise required disclosure of the authorship and financing of such advertising; and it facilitated the reliance of campaigns on hard money by

Richard L. Hall is a professor of political science and public policy at University of Michigan. An earlier version of this article was presented at the 2003 annual meetings of the American Political Science Association and the Public Choice Society. Ann Lin helped originate the idea for the article and deserves as much credit or as little blame as she cares to take. For helpful comments, thanks go to Bob Axelrod, Ken Kollman, Kelly Hall, Tom Mann, Robert Van Houweling, two anonymous referees, and the editors of this journal. doubling the limits on individual contributions to candidates.

These are significant reforms all, and they are already exhibiting important effects on federal campaign politics. ${ }^{2}$ Although a full-blown assessment of those effects is not the purpose here, two features of the post-BCRA environment suggest that additional and different reforms may be needed. First, the private money still flowing into congressional campaigns in large quantities continues to threaten the democratic integrity of post-election policymaking. Second, campaign spending disparities between incumbents and challengers remain extreme, and those disparities contribute to the non-competitive nature of congressional elections. As a result, the values of voter choice and democratic dialogue are diminished.

These two problems motivate what follows. After briefly discussing their importance, I introduce for discussion a new approach to federal campaign finance reform. The main idea is to legally authorize and privately endow a nonpartisan "expenditure equalizing commission" (EEC) - a nonprofit entity whose sole mission would be to diminish inequalities in campaign advertising expenditures across candidates for the same congressional office. An EEC would be able to raise funds from any source in unlimited amounts, but the commission would provide matching grants only to general election candidates who are being significantly out-

\footnotetext{
${ }^{1}$ See Cooper (1999), esp. the selections by Bradley, Shribman, and Cooper.

${ }^{2}$ For a thorough analysis of the BCRA's various effects on the 2004 election, see Malbin (2006).
} 
spent by their opponents. No conditions or restrictions would be placed on the recipients; indeed, grant monies would go to eligible candidates automatically according to a predetermined formula. For practical reasons discussed below, the EEC would begin by equalizing spending in open seat races. Once an open seat has been filled, subsequent races for the same seat would be eligible for EEC subsidies whether or not an incumbent is seeking reelection.

As such a campaign system fully matures, several salutary changes should follow. First, the prospect of automatic subsidies to otherwise financially disadvantaged candidates should induce higher quality challengers in both parties to run for office. The result should be increased competitiveness and more informative debates in congressional elections. Second, the matching nature of the subsidy will increase the incentive of disadvantaged candidates to raise money through smaller contributions and increase the incentives of small and large contributors to give them more. Third, the equalizing nature of the subsidies will reduce the incentive of financially advantaged candidates to raise and spend ever larger sums, and it will reduce the incentives for their contributors to contribute. The arms-race nature of campaign fundraising should thus diminish, as neither candidate could expect to outspend the other. Fourth, parity in candidates' campaign spending should go up while the importance of interest group contributions should go down. This, in turn, should diminish the political indebtedness of winning candidates to moneyed interests in post-election policymaking, what most observers take to be the most important goal of campaign finance reform. Finally, the EEC lacking any authority to regulate the speech or expenditures of any campaign actor, all of the above can occur without infringing First Amendment guarantees of free speech and association. A major concern of past campaign reform debates will be avoided and an important constitutional value protected.

This article develops this proposal in preliminary form, exploring ways the institution and procedures might be designed and implemented. In such an introduction, to be sure, nu- merous problems will be given short shrift; important devils will remain in the logistical details. Although the proposal is fashioned with an eye to political viability, that viability turns first on the merits of the proposal, merits about which reform advocates will invariably disagree. In vetting it here, the hope is to explore its possibilities, identify some of its limitations and, more generally, to incite further discussions about new ways to disengage big money from congressional politics in the post-BCRA era.

\section{MONEY IN CONGRESSIONAL POLITICS POST-BCRA}

As with most reforms proposals, the BCRA was not designed to solve all of the problems of money in politics. Those who participated in developing the main elements of BCRA acknowledged that its main purpose was but "to repair egregious tears in the regulatory fabric" of campaign finance law, rent by the growth of soft money and electioneering masquerading as issue advertising (Mann and Ornstein 2002, 3). The act would thus "reinstate the status quo ante of barely a decade ago" (Mann and Ornstein 2002, 3; Jacobson 2006, 201). Were the law to do that much, its achievement would be substantial. ${ }^{3}$

That said, there is more that needs to be done. Three points warrant emphasis. First, the BCRA did not address problems of hard money, problems long thought to be serious before the growing abuses of soft money in the 1990s. Political Action Committee (PAC) contributions financed over $40 \%$ of House and $20 \%$ of Senate campaign receipts in 2004, roughly the percentages for the prior two elections. More disturbingly, contributions from single industries or economic sectors (e.g., agribusi-

\footnotetext{
${ }^{3}$ So far it seems that the Act has been partly successful. An analysis of BCRA's effects based on the 2004 elections can be found in Malbin (2006). Among that volume's main conclusions: (1) Less than half of the soft money banned by the act found its way into the elections through 527 organizations or other routes (Weissman and Hassan 2006); (2) The new electioneering rules "had only marginal effects on interest group advertising in 2004" (Boatright et al. 2006, 113). See also Franz et al. (2006).
} 
ness, oil and gas, health professionals) generated $\$ 100,000$ or more for dozens of incumbents well-placed to affect industry interests. ${ }^{4} \mathrm{Sec}-$ ond, advertising by advocacy organizations on behalf of candidates doubled from 2000 to 2004 (Boatright et al. 2006), and constitutional principles make this money difficult to regulate. Third, as much as half of the soft money banned by the BCRA has rematerialized as spending by Section 527 organizations. In short, whatever democratic illness private money caused in years past, the BCRA of 2002 has not fully cured.

To be sure, the nature of that illness is often mischaracterized. The problem is not so much that too much money is being spent on campaigns (Ansolabehere, de Figueiredo, and Snyder 2003), public perceptions to the contrary. Nor is there strong evidence that we have The Best Congress Money Can Buy (Stern 1998), sensationalist allegations not withstanding. Social scientific studies of PAC money's influence on roll call votes have proved mixed, for good theoretical and methodological reasons. ${ }^{5}$ Insofar as we can tell, straight bribery is not the primary virus. But as the Supreme Court acknowledged in McConnell v. FEC, it need not be. ${ }^{6}$ The government has a legitimate interest in preventing "more subtle but equally disquieting forms of corruption ... neither easily detected nor practical to criminalize. ${ }^{7}$ Especially disquieting is the considerable evidence that even if money does not influence elections or roll call votes directly, it facilitates access and otherwise "buttresses lobbying activities" (West and Loomis 1999, 228-229) meant to influence legislators' priorities or their less visible legislative efforts off the floor (Evans 1996; Hall and Wayman 1990). ${ }^{8}$ The overwhelming tendency of PACs to give heavily to incumbents not in danger of defeat and to well-placed allies whose favorable votes on legislation are already assured is difficult to explain otherwise (Grier and Munger 1993; Hall and Deardorff 2006). More direct evidence that money enhances access to influential legislators comes from a variety of sources, including reports of congressional insiders, ${ }^{9}$ limiting cases, ${ }^{10}$ comparative case research, ${ }^{11}$ and quantitative analysis. ${ }^{12}$ There is evidence enough to worry that such money magnifies the voice of contributors and thus fosters unequal representation, thereby damaging the democratic integrity of the legislative process (Gais 1996; Lowenstein 1989).

\section{ELECTORAL COMPETITION AND INEQUALITY IN CONGRESSIONAL CAMPAIGN SPENDING}

Starkly evident in the first congressional elections post-BCRA is the scarcity of meaningful competition. By most measures, the 2004 House elections were the least competitive in history. Ninety-five percent of the House races were won by margins greater than $10 \%$; $85 \%$ were won by margins greater than $20 \% .{ }^{13}$ The odds of House incumbents retaining their seats in the first election post-reform were about 60

4 The Center for Responsive Politics matches employee contributions to their economic sector in compiling sector totals. See $<$ http://www.opensecrets.org/bigpicture/ bundles.asp? cycle $=2004$ \&type $=S>$.

5 Though even here, Stratmann (2005) finds in a metaanalysis of 36 studies that PAC influence does influence roll call voting. For a skeptical review of vote-buying, see Wright (1996).

${ }^{6}$ McConnell v. Federal Election Commission, 540 U.S. 93 (2003).

${ }^{7}$ McConnell v. Federal Election Commission, at 153.

${ }^{8}$ For a more general argument about the insidious effects of private money, see Lowenstein (1989).

${ }^{9}$ Among a long list of insider-based work, see especially Makinson (2003). Of the sixteen current and former members and eight interest group representatives interviewed for Makinson's book, "virtually everyone accepted the long-held Washington premise that money buys access" (p. 59). For wide-ranging investigative reporting that supports this point, see Birnbaum (1992).

${ }^{10}$ One such case is Senator John Kerry's 2004 partial release of his office records regarding meetings with lobbyists, a ploy to upstage Bush on matters of White House secrecy and cronyism. Presumably Kerry would not have released the records, or would have done so even more selectively, if he did not think his granting of access largely unimpeachable. A Washington Post analysis showed that the list included dozens that had business before Kerry's Senate committees, including his top contributors, and even then the Post determined that the list was grossly incomplete. See VandeHei and Birnbaum (2004).

11 See, e.g., West and Loomis (1999).

12 See e.g., Langbein (1986); Langbein and Lotwis (1986); Hall and Wayman (1990); Hojnacki and Kimball (1998); Tripathi, Ansolabehere, and Snyder (2002); Wright (1990). ${ }^{13}$ For congressional election statistics used here, see the Center for Responsive Politics website: <http://www. opensecrets.org $/$ bigpicture $/$ reelect.asp? Cycle $=2004>$. 
to 1 , tied for the highest reelection rate in the modern Congress. So too in the Senate: $96 \%$ of the senators who sought reelection won in 2004, compared to $86 \%$ in 2002 and $79 \%$ in 2000. Taken together, $94 \%$ of Senators and House members who sought reelection in 2006 wonthis in a year of dramatic party reversal.

Of course, many factors unrelated to campaign finance contribute to incumbents' electoral advantage, not least of which are constituency service, pork barrel politics, and political redistricting. But fundraising disparities matter, and campaign spending is dramatically unequal between congressional incumbents and challengers. In 2004, the fundraising advantage of House incumbents over challengers increased by $\$ 230,000$ - from a ratio of $41 / 2$ to 1 to almost 6 to 1 ; in Senate races, the gap grew by almost $\$ 3$ million, from a ratio of less than 6 to 1 to almost 9 to $1 .^{14}$ The problem these disparities reflect, however, is not that general election spending allows incumbents to trample their challengers. Rather, the anticipation of the incumbent's fundraising advantage discourages potentially strong challengers from running. ${ }^{15}$ Not wanting to devote a year or more of their lives to fundraising, only then to be outspent, politically experienced individuals decide to remain in their current positions, to wait for an open seat, or to pursue more promising avenues for advancement. Incumbents, as a result, face weaker challengers, who, because they are weak, raise less money.

A closely related consequence is that capable candidates who might articulate different views or give voice to constituents and groups outside the incumbent's electoral coalition are "censored" by the campaign finance system. Having never entered the race, they are not heard or observed, making the electoral forum a less meaningful site for the competition of ideas as well as candidates. As the Supreme Court has recently suggested, preventing the discouragement of candidacies is a value worth preserving. In Randall v. Sorrell, the Court nullified Vermont's exceptionally low contribution limits in part because they magnified incumbency advantages and undermined electoral accountability:

[C]ontribution limits that are too low can also harm the electoral process by pre- venting challengers from mounting effective campaigns against incumbent officeholders, thereby reducing democratic accountability. Were we to ignore that fact, a statute that seeks to regulate campaign contributions could itself prove an obstacle to the very electoral fairness it seeks to promote. (Randall v. Sorrell, 126 S.Ct. 2479, 2492 (2006)).

The problem thus becomes how to enhance competition and dialogue without regulating the spending or speech of candidates or imposing tight restrictions on the contributions of voters or parties. The challenge, in other words, is to more nearly equalize spending without restricting it.

In what follows, I sketch a new approach to campaign finance with the above problems in mind. The next section describes the key elements of the proposal, inviting the reader to identify political and substantive problems, reflect on proposed and alternative provisions, or simply grunt disapprovingly along the way. The purpose here is not to articulate and defend a full-blown proposal for reform. Rather, it is to initiate a broader discussion about campaign finance reform post-BCRA and in particular about one approach, an approach that builds upon normative standards of equal representation, electoral competition, and informative debate.

\section{THE EXPENDITURE EQUALIZING COMMISSION}

The main idea of the present proposal is to legally authorize and privately endow a new campaign finance institution, the Expenditure

\footnotetext{
${ }^{14}$ Calculated from numbers reported at: <http://www. opensecrets.org/bigpicture/incumbs.asp?Cycle $=2004>$. ${ }^{15}$ The literature on this point is substantial. See, e.g; Goldenberg, Trauggott, and Baumgartner (1986); Snyder (1992); Epstein and Zemsky (1995); Stone, Maisel, and Maestas (2004); Levitt andWolfram (1997); Box-Steffensmeier (1996). On the self-reinforcing disadvantages of anemic challenger fundraising generally, see Krasno, Green, and Cowden (1994). For a dissenting view that incumbent war chests do not affect candidate entry, see Goodliffe (2001).
} 
Equalizing Commission (EEC). Using income from its endowment, the EEC would distribute matching campaign funds, automatically and without conditions, to eligible congressional candidates according to one simple principle: Minimize inequalities in "public communication" expenditures ${ }^{16}$ for the two (perhaps more) viable candidates running in the general election for the same congressional office. ${ }^{17}$ Thus, during a given election cycle, the automatic grants would variously subsidize Republicans and Democrats and possibly third party candidates, conservatives and liberals, competitors for open seats, and when fully mature, challengers and incumbents. In this section, I lay out the proposal's key features, then turn in the following section to an analysis of its virtues and vices.

\section{Endowment}

EEC contributions to candidates will be financed from the income on a private endowment. Such an endowment will need to be very large, even if the plan is applied initially to only one chamber. The enabling legislation for the EEC would thus allow it to receive contributions unlimited in size and number from any source-individuals, corporations, labor unions, public interest groups, foundations, and other non-profits - though for political reasons they would not be tax-deductible. The size of the endowment potentially needed and the problems of raising it are taken up below. But for now, the feature worth emphasizing is that once the necessary endowment is raised, the fix for campaign finance will become permanent in a way that most public financing proposals are not. No annual or biannual budget fights over government campaign spending will arise; no raids on, say, a trust fund budget would be possible. Indeed, no taxpayer dollars will be at stake; thus no anti-government or anti-politician sentiments can give traction to the Commission's opponents.

\section{Governance}

The EEC would be a non-profit entity, whose legal organizational form will remain undefined here. However, the general idea is that it be something like a quasi-governmental orga- nization on the order of Fannie Mae or Freddy Mac or a new type of foundation, which new statutory language would need to authorize. Alternatively, it might be defined under the Federal Election Campaign Act (FECA) as a new type of campaign finance entity, not subject to the restrictions of campaign committees, parties, or PACs.

Like a foundation, the EEC would be governed by a board of trustees. Each EEC trustee would have a fiduciary responsibility to see that EEC funds are spent to advance its sole mission of diminishing inequalities in advertising expenditures for candidates running for the same congressional office. The authorizing legislation would need to specify how the initial trustees would be selected, but any of several mechanisms could work. For instance, the current FEC might compile an expansive list of individual nominees including (i) former FEC professional staff, (ii) retired judges with experience in FECA cases, and/or (iii) non-partisan legal and foundation experts specializing in areas relevant to campaign finance and electoral politics. Those on the list could then select, say, eleven from among themselves through approval voting or some other means. To monitor for possible partisan bias that might nonetheless arise, likewise, each of the two national parties might also select one trustee. Trustees would serve a fixed term, with the initial terms staggered. New trustees would be selected in

${ }^{16}$ By "public communication expenditures," I mean the more expansive McCain-Feingold definition of "Public Communications," (BCRA amendments to Sections 301(b)(22), 301(b)(23), and 301(b)(24) of FECA of 1971 (2 U.S.C. § 431)). That definition reads: "The term 'public communication' means a communication by means of any broadcast, cable, or satellite communication, newspaper, magazine, outdoor advertising facility, mass mailing or telephone bank to the general public, or any other form of general public political advertising."

17 Limiting EEC subsidies to general election candidates creates a number of potential problems, which for present purposes are swept under the rug. For instance, a majority legislator in a one-party state or district would be more indebted to unions or industries for providing the funds she needed to win her primary. I focus solely on the general election here (i) so as to convey more clearly the working features of the proposal and (ii) as a concession to EEC logistics and costs. Ultimately, both primary and general elections would need to be subsidized through an EEC mechanism. 
the same way from subsequent lists compiled by the Board. The goal here, in any case, is to develop a process that selects individuals with a reputation for integrity, non-partisanship, and a commitment to the organization's mission.

\section{Eligibility criteria}

A more important means of insuring the EEC's reputation for legitimacy is to lay out its grant-making process and criteria in its founding charter, so as to make its decisions as mechanical as possible. For the duration of any given campaign, the eligibility standards for candidates to receive EEC funds and the EEC's allocation formula for awarding them would be fixed, thereby limiting opportunities for partisan mischief. The specific criteria and thresholds for awarding campaign finance grants will need to be worked out in greater detail than is possible here. The following particulars are offered to suggest some questions that will need to be faced and possible means for addressing them.

The principal activity of the EEC would be to allocate funds based on a formula, driven by the campaign communication expenditures of the financially advantaged candidate in the race. The idea is to give matching grants to financially disadvantaged candidates to help them diminish the gap in communication spending between them and their opponents. However, contributions to the needier candidate would not be guaranteed. As with the presidential campaign financing system, minimal eligibility criteria would insure that the EEC does not waste funds on long-shot candidates, that is, on races that are unlikely to generate a remotely competitive race even if their campaigns receive EEC subsidies. Thus the EEC would require that the applying candidate be minimally "viable." Viability criteria would include some combination of the following: (i) The candidate's national party organization has already contributed the maximum amount to her campaign allowable under law. (ii) The candidate has already raised a certain threshold of campaign funds on her own, in the form of a specific fraction (say, one-fourth) of the other candidate's receipts (thus tailoring the threshold to the variable campaign costs dis- trict to district). (iii) An independent poll shows that the candidate exhibits voter support above some specific threshold (say, 30\% in a two-way race) by the beginning of the general election campaign. In setting precise viability criteria, however, the trick will be to set them high enough that they exclude lost causes in search of a soapbox but not set them so high that the EEC fails to serve its pro-competitive purpose. Specifically, the threshold needs to be low enough that high-quality candidates considering a run can reasonably anticipate that they will qualify for EEC funding.

\section{Allocation formula}

The EEC would allocate funds on a matching basis so as to help disadvantaged candidates achieve effective equality with the campaign communication expenditures by or for their advantaged opponents. The funds would come in the form of a matching grant, capped at onethird of the gap in the two candidates' postnomination communication expenditures. ${ }^{18}$ About this formula, four points:

(1) The sufficiency of a one-third cap in achieving "effective equality" follows from the substantial body of research showing that campaign spending in the general election helps under-funded challengers far more than resource-rich incumbents. ${ }^{19}$ The latter simply hit a point of diminishing marginal returns more quickly than do their opponents. Until recently, in fact, a long line of studies found that higher campaign spending by incumbents actually decreased incumbent vote share. A recent paper by Stratman (2004) has adjusted for significant measurement error in candidate spending, however, finding that the incumbent's marginal product of advertising is, in fact, positive. Even so, it is smaller for incumbents than chal-

\footnotetext{
18 Of course, subsidies would likewise cease should the EEC-supported candidate's campaign exceed her opponent's expenditures. At that point, the financially advantaged candidate becomes the disadvantaged one and could qualify for EEC grants.

${ }^{19}$ See Jacobson (1978) for the seminal statement of this finding. The subsequent literature is nicely summarized in Stratmann (2004). As an illustration, the five challengers who defeated incumbents in 2004 spent on average about $\$ 400,000$ less than the incumbents.
} 
lengers. A ten percent increase in spending for incumbents, Stratmann finds, accounted for up to a $1 \%$ increase in vote share, whereas for challengers it accounts for up to a $1.5 \%$ increase. Using Stratmann's calculation of candidates' marginal products, equality of campaign advertising product can thus be achieved for the challenger at two-thirds of incumbent communication expenditures. Assuming that high quality candidates, with their newly motivated contributors, could raise funds at the margin enough to finance one third of the gap, the EEC match would cover the other third. ${ }^{20}$ For open seat races, likewise, $67 \%$ should be adequate in that such races are inherently more competitive on financial and non-financial grounds.

(2) Communication expenditures will be matched rather than total campaign expenditures, because a substantial share of a candidate's total expenditures goes to overheadstaff salaries, travel, fundraising events, and the like-whereas EEC grants would come with virtually no overhead. Ansolabehere and Gerber (1994) have calculated that candidates spend on average two to three dollars out of five on "voter contact," the definition of which is only a little broader than the BCRA definition of public communication expenditures. If acquiring timely, detailed reports on candidates' communication expenditures proved unworkable, the Commission fallback formula could simply be $40 \%$ of total campaign expenditures (or even receipts) as an approximation of public communication spending.

(3) The matching formula could provide variation according to size and source of the contribution, ideas rehearsed in earlier reforms at the state and federal level. For instance, in order to provide incentives for financially disadvantaged candidates to seek out a broader, if costlier-toreach, donor base, the EEC could set a higher matching rate for money raised through small individual contributions, say, under $\$ 500$ (e.g., $\$ 2$ for $\$ 1$ ), and a lower matching rate (e.g., \$1 for \$1) for larger contributions from individuals, perhaps a still lower match (e.g., \$1 for \$2) from PACs. ${ }^{21}$ Likewise, the matching formula could be made more generous for within-district/state contributions from individuals.

(4) All communications by or on behalf of a candidate would count toward the candidates' communication expenditures, including personal funds or electioneering communications by advocacy organizations, as those expenditures are defined by the BCRA. ${ }^{22}$ Hereafter, I include them whenever referring to a candidate's communications or advertising expenditures. Insofar as the interest group expenditures can be counted, the EEC matching feature should diminish interest group incentives to circumvent the spirit of Federal Election Commission (FEC) regulations on electioneering.

\section{Grandfathering incumbents}

In the beginning the EEC would only operate in races for open seats; then it would remain operable in all subsequent elections for that seat, even when an incumbent is running. ${ }^{23}$ In effect, current but not subsequent incumbents would be grandfathered under this proposal. ${ }^{24}$

Several reasons justify this provision. First, it is unreasonable, perhaps even a bit unfair, to expect career politicians, who have invested a great deal in developing a campaign infrastructure under long-standing rules of the

${ }^{20}$ At designated intervals, the EEC would calculate the gap in relevant spending by the two candidates. Subsequent spending by the underfunded candidate of up to one-third of the calculated gap would be designated for matching purposes, thus avoiding the situation where the raising and spending of matching funds make the gap calculation a moving target.

${ }^{21}$ On the benefits of graduated matching, see Campaign Finance Institute Task Force (2003).

22 Proposed amendments to BCRA would require the FEC to regulate Section 527 organizations according to the same reporting guidelines and spending limits as political action committees. Such an amendment would make it possible to incorporate 527 spending into the matching calculations proposed here, thereby creating disincentives for $527 \mathrm{~s}$ to continue to raise and spend large sums. In the short run, at least, such a change would also increase significantly the cost of the EEC. Briffault (2005) argues that subjecting 527s to regulation may run afoul of constitutional concerns. For the purposes here, however, timely reporting by 527s to the FEC is all that would be required. ${ }^{23}$ Races would be eligible for EEC funds post-reapportionment if and only if there is no grandfathered incumbent running, including cases where redistricted incumbents are running against each other.

${ }^{24}$ It should be noted that grandfather provisions have their precedents in previous congressional campaign-related reforms. In the late 1980s, Congress passed new restrictions that prohibited members of Congress from converting leftover campaign cash to personal use. The law employed a grandfather clause that allowed such conversions for incumbents who left office by 1992. 
game, to selflessly deflate that investment's value. The grandfathering need not be indefinite, however. Limiting it to, say, five campaigns would be enough for current House incumbents, two campaigns for Senate incumbents, to adapt their organizations to a new set of rules.

Second and more importantly, a grandfathering provision should diminish incumbents' opposition to legislation enabling the creation of an EEC. The perennial problem in campaign finance reform politics is that the very politicians who have succeeded under the existing system are the ones who must change it. As I have noted, incumbents tend to enjoy a substantial fundraising advantage over potential challengers. It is more than a little unlikely that sitting members of Congress would accept a system that would generate stronger challengers to them in the next election. The relatively small size of the maximum EEC subsidy should diminish that opposition, but grandfathering will do so more effectively.

A third reason goes to the proposal's financial viability. Below I take up the potential costs of the proposal and the size of the endowment that would be required. Suffice it to say here that with the EEC at first in the business of only subsidizing races for open seats, the short run costs would be considerably lower and the time available for raising a substantial endowment considerably longer.

\section{Immediate reporting}

Most of the important advertising occurs in the last weeks of the campaign. Hence, for our EEC subsidies to have their equalizing effect, candidates, parties, and independent organizations would need to report advertising buys to the FEC on-line at the time of purchase (contract) for all advertising being run in the last month of the election. This would permit timely allocations to "under-funded" candidates by the Commission during the late stages of a campaign. In addition, the BCRA closed certain disclosure loopholes that had thwarted transparency and accountability over the last several elections. Fortunately, we are at a stage in the information age when instantaneous transmission of information is not only possi- ble but cheap. Were the timely reporting of campaign communication expenditures nevertheless to prove too cumbersome, then as I have suggested above, $40 \%$ of receipts could serve as a reasonable approximation.

\section{VIRTUES}

As I have pointed out along the way, the benefits of introducing an EEC into the campaign finance system would be several and important. This section reviews them and considers some additional ones.

\section{Changed incentives, voluntary reform}

The most important feature of this proposal is that it operates through a mechanism quite different from current campaign finance law. Almost all campaign finance plans, at both the state and federal level, have attempted to limit the size of contributions to various political actors and, directly or indirectly, control the level of campaign spending. Thus is campaign finance law regulatory and proscriptive. As such, actors in the system are naturally inclined to find creative but legal ways of circumventing the constraints foisted upon them. Sooner or later, they do. The EEC proposal benefits from some of the campaign finance regulations already in place, but it proceeds in a different way. It aims to restructure the incentives of actors in the system so that their purposive, voluntary behavior will promote rather than circumvent the equalizing objectives of reform.

\section{More competitive elections, more informative speech}

The straightforward implication of the change in challenger incentives brought about by the EEC subsidies is that more congressional races will be competitive. The subsidizing nature of the plan would increase the incentives of high quality candidates to run for congressional office, thereby enhancing competitiveness. Without having to raise nearly as much money, they can anticipate that they will not be substantially outspent. Likewise, raising money will be easier. The matching nature of the subsidies will increase the fundraising abil- 
ities of financial underdogs by increasing the incentives of potential contributors to contribute (or to contribute more).

The equalizing nature of the grants, in turn, will diminish the incentives of incumbents or other financially advantaged candidates to solicit ever greater donations. Potential contributors to incumbents, likewise, will have less incentive to contribute. Why make a donation if it is going to be largely offset by EEC money going to the opponent? The deterrence to candidacies caused by incumbent fundraising would thus be curtailed. A related implication is that incumbents will be less likely to run unopposed, at least in areas where viable competition is feasible. Candidates with different ideas or appealing to previously unrepresented constituencies will have a greater opportunity to enter the political debate.

\section{More parity in spending}

Ceteris paribus, parity in candidates' campaign spending should go up. As emphasized above, automatic EEC subsidies to the financially disadvantaged candidate should reduce the incentive for advantaged candidates to raise extremely large sums of money. Rather, they should seek a level of spending up to the point where the marginal return in election probability per dollar spent, given the other candidate's matched fundraising, approaches zero. That is, more spending is better only if the candidate thinks he needs it more than his opponent. So too with the challenger. Should she take the spending lead (above some minimum threshold), the same disincentive would then apply to her, as her fundraising would trigger matching grants to the formerly advantaged opponent. The arms race should thus become self-regulating.

Less post-election indebtedness to private groups

Automatic EEC subsidies should induce special interests to contribute less to well-positioned members. As a consequence, the subsidies should diminish the dependence of legislators on contributions from organizations who foresee that their interests in legislation or oversight will come before Congress. While money at the challenger's margin will be matched for free by the EEC, the cost of raising money for the incumbent will go up after the easy donors have been tapped. Should the challenger (or under-funded incumbent) win, in turn, a significant portion of her campaign expenditures will be financed not by private groups but by the EEC, which will not seek to cash in any policy debts after the election.

\section{No First Amendment problems}

Given that the EEC will only enable speech rather than restrict it, First Amendment objections to this campaign finance reform disappear. Those who have wrestled in the campaign finance reform arena over the last decades will recognize this as a major political as well as substantive virtue. Even though the Supreme Court has resolved the constitutional doubts about BCRA restrictions, future reforms that avoid further insults to the First Amendment will doubtless be politically stronger. ${ }^{25}$

\section{Money without ideological or partisan bias}

The EEC will be non-partisan by its charter. It will give to Democrats, Republicans, and even third party candidates according to eligibility criteria and allocation formulae consistent with the charter and consistent across candidates and races. While it is difficult to know, the introduction of neutral funds into the system might also diminish the polarization generated by candidates' financial dependence on ideological and single-issue groups.

\section{Public-like financing without public financing}

Many reformers have long thought public financing to be the optimal-but politically least viable-form of campaign finance reform. The political difficulties result in large part from

\footnotetext{
${ }^{25}$ Campaign reforms built upon McConnell v. Federal Election Commission may not be on perfectly firm ground. Richard Briffault (2002) argues that "McConnell is as precarious a victory for reform as it is sweeping. Both the specific holdings and the Court's basic approach to campaign finance restriction could be dramatically transformed if and when the membership of the Court changes." Of course, with the replacement of Rehnquist and O'Connor by Roberts and Alito, that membership has changed.
} 
public reluctance to pay the cost out of tax funds and in part from ideological objections to government participation in election campaigns. The EEC proposal provides the benefit of disinterested campaign financing without the taxpayer cost of public financing and without triggering the ideological objections.

\section{Relief from the money chase?}

As a general matter, it is not obvious that too much is being spent on congressional campaigns (Ansolabahere, de Figueiredo, and Snyder 2003). Within broad limits, campaign advertising is actually quite informative, charges about advertising's bias and emotional manipulation notwithstanding (Brader 2005). But it is a problem that incumbent legislators and their party leaders spend too much time raising funds. The more private fundraising that legislators do, the more time they are giving informal access to lobbyists who represent industries and groups able to make substantial contributions. Magleby and Nelson (1990) refer to this as "the money chase." One member reported that it makes him "feel unclean." And it is one of the most common complaints that members of Congress express about their jobs. For some, it has become so burdensome that they might sympathize with a system that reduces it, even if it will only benefit their successors. Lobbyists likewise complain about members of Congress regularly "shaking them down" for contributions. Beyond that, Magleby and Nelson observe, the money chase takes up a great deal of a legislator's time-time better spent meeting with rank and file voters, overseeing agencies, or drafting legislation.

Under the present proposal, however, it is not obvious that total spending would go down. One of the most important objectives of the equalizing formula is to encourage higher quality candidates to run. Campaigns should thus become more competitive, and competitive races should exhibit higher spending by both candidates, ceteris paribus. The net effect of this proposal on aggregate spending should thus vary across races, but, even so, the incumbent's incentive to create exorbitant war chests should be undercut. His money chase should thus slow down.

\section{Democratizing money?}

The prospect of matching funds increases the incentive of candidates to pursue smaller contributions. A higher match for small contributions would directly promote that, but even a standard 1:1 match would do so in that it doubles for every donor the marginal benefit without doubling the marginal cost. To the extent that current campaign messages are developed with an eye to donors as distinct from voters, more inclusive fundraising strategies may also shape the campaign dialogue as well.

\section{VICES}

Of course, one can immediately think of substantial counterarguments to the reform proposal outlined here. I will take up three classes of problems, leaving the most importantproblems of political viability-to the following section.

\section{Strategic incumbents}

One of the principal purposes of this plan is to increase competitiveness in congressional elections, mainly by encouraging quality challengers to run. If they do, they raise more money and they receive more grants. At the same time, the proposal would make it difficult for a challenger to significantly outspend an incumbent. ${ }^{26}$ In fact, it is possible that incumbents would adapt to the new system by pursuing the exact opposite of a preemptive strategy. Incumbents might raise and spend very little and thereby ensure mutual silence because their competitors, not being outspent, would not qualify for EEC subsidies. Without the ability to spend a substantial sum, in turn, challengers could not overcome the natural advantages of incumbency, such as name recognition, media attention, casework, and the like.

\footnotetext{
26 The evidence suggests that for challengers to defeat House incumbents they need to spend a great deal of money-over \$1.5 million on average in 2002 and 2004but it is not necessary to outspend incumbents. In only two of the last ten election cycles have successful challengers averaged higher spending than the defeated incumbents. See < http://www.opensecrets.org/bigpicture/ cost.asp $>$.
} 
Challengers would be left to their own fundraising devices, and what funds they raised, ironically, could be matched by grants to the underfinanced incumbent. The probable result: a non-competitive race and a less-informed electorate, just the opposite of the proposal's intentions.

Three reasons make this strategy less likely in practice than reasonable on paper. First, it would probably appear counter-intuitive and more than a little risky for an incumbent to assume that he would win more votes by advertising less. Indeed, a sit-out-the-campaign strategy might itself generate criticism from supporters and the media. Second, the quality challenger's incentive to run in the first place and hence her ability to raise funds would still be enhanced, as both the potential challenger and the potential donors would know that the incumbent employing this strategy will not effectively outspend the challenger. The presence of a quality challenger advertising against him, in turn, would likely stimulate the defensive instincts of the incumbent, leading him to raise the money for a serious campaign.

Third, even if an incumbent strategy of quiescence were to undercut competitiveness, it would also leave the reelected incumbent without indebtedness to private donors. Nor would the incumbent have spent weeks of work-time every year holding fundraisers and feeling unclean. Given that incumbents overwhelmingly win in the present system, the proposal would thus do no worse than the status quo on competitiveness but would be considerably better at disengaging big money from congressional politics.

\section{Interest group circumvention}

Money can enter a campaign through various sources other than the campaign committees of individual candidates and their parties. The flow of such money was regulated by the provisions regarding "electioneering communications" in the BCRA, but these restrictions do not ban such communications, they only regulate their source and timing. Other organizations, such as interest group PACs, can spend unlimited amounts on advertising to promote a candidate of their choosing, so long as their efforts are not coordinated with the candidate's campaign. Coordinated or not, such money could generate a sense of indebtedness and thus be damaging to the integrity of post-election policymaking. Under the present proposal, such money spent demonstrably on behalf of a candidate would be counted as candidate expenditures and subject to an EEC match.

More problematic for the present proposal, as for the BCRA itself, is the unregulated money introduced through Section 527 organizations. 527s are tax-exempt entities whose purpose is to influence federal elections but who are unregulated in the size and source of the contributions they receive. They entered campaign politics in force in the 2004 presidential elections, but their efforts carried over to the 2006 congressional elections as well. The problem here is that so long as their advertisements avoid direct endorsement or opposition to a specific candidate, they are not subject to hard money regulations. That they do not engage in express advocacy, in turn, makes their spending difficult to classify as being on behalf of a particular candidate. For EEC purposes, it would be unworkably time-consuming and perhaps unacceptably discretionary to attempt to make this classification. Moreover, many interest groups with 527s also have PACs and 501(c) organizations that coordinate their electoral strategy, such that changing the incentives of one may be offset by changes in the strategies of the other (Weissman and Ryan 2006).

Campaign finance reform advocates have argued before the FEC and Congress that 527 organizations should be treated as political action committees subject to regulations governing hard money. Such changes would be necessary if EEC subsidies are to deter these shadow committees from frustrating the goal of equalizing spending.

\section{Lurking partisanship?}

The EEC will need to project an image of fairness to politicians and the public and especially the organizations and individuals who might fund its endowment. The EEC system will thus be non-partisan in its membership (save for two party representatives), governance, eligi- 
bility criteria, and allocation formulae. Commission members will have no role in fundraising for the endowment, and they will make discretionary decisions about cases by means of a "blind review" whenever possible. Nonetheless, the recent history of the FEC leads one to worry whether the commission proposed here can achieve-and project-a high degree of non-partisanship. This is no small matter, and it is difficult to predict. As much as any other feature of the system, this will require greater attention if the proposal is to go anywhere.

For purposes of the proposal's political viability, it may be even more important that key partisans in Congress believe that aside from the partisan fairness with which the EEC system is implemented, it will tend to be non-partisan in its effects. This will concern even grandfathered incumbents, who care about the new institution's implications not only for their own electability but for whether their party holds the majority. The current evidence suggests that the time may be right for an EEC-style reform on the House side. The number of incumbents is about evenly split between the parties. So far under the BCRA, neither party seems to have a clear fundraising advantage, at least insofar as hard money goes. The advantage of Republicans in House races grew in 2006, but the advantage of Senate Democrats went up even faster. Ultimately the advantage may go to the Republicans, mainly because of the doubling of the contribution limits for individuals. But the electoral effect will be hard to infer, in part because the House Republican fundraising advantage in 2006 produced a Democratic majority. Looking to the long run, it probably will be difficult for either party to adopt firm beliefs that the BCRA system favors them more than the proposed one.

\section{A non-adaptive institution?}

The very fact that the EEC may prove insulated from political bias, however, may mean that it is not easily adapted to the inevitable changes in campaign finance practices that emerge over time. Presumably the governing board, because of board members' greater understanding of electoral and campaign finance practice, would be better able than most rep- resentative bodies to adapt, subject to its expenditure equalizing mandate. Should the EEC's equalizing role be outstripped by new and larger funding sources, its continuation would at worst do no harm-an advantage one cannot always ascribe to well-intended reforms.

\section{VIABILITY}

To this point I have begged the question of whether an expenditure equalizing commission could be created in the first place. What is its political viability? Here is the main catch.

As with any other reform proposal, there would need to be enabling legislation. Specifically, the EEC would require a special exemption under FECA to receive large donations from foundations and other large benefactors. It would likewise need an exemption to contribute potentially large sums of money to particular congressional candidates. Significant changes in campaign finance law, as we have seen over the last six years, are difficult to make, and the passage of the BCRA may have satisfied demand and taken the issue of reform off of the legislative agenda for some time. This is hardly the only problem with the plan's political viability, however.

\section{Incumbents relinquishing advantage!?}

The ever-present obstacle to campaign finance reform is that incumbent politicians, successful under the current system, have inherent disincentives to change it. Other things equal, change raises their uncertainty about remaining in office. Enacting a statute authorizing an EEC whose purpose is less than incumbent-friendly will be difficult, to say the least.

The grandfathering provision is intended to mitigate that problem. As seats come open in one cycle and the new incumbents seek reelection in the next, the scope of the EEC's reach will gradually expand. Present incumbents otherwise threatened by a new campaign finance institution would have little to fear individually for several elections, and over time, an increasing number of representatives will be elected with the aid of EEC funds. After five elections, all candidates would be covered. 
Two other features should make the proposal politically more attractive. First, it erases the (perceived) threat to incumbents posed by "millionaire" candidates, i.e., those individuals who can use their personal wealth without restriction to run high-priced campaigns. The BCRA's "millionaire amendment" partly addressed this advantage by allowing higher limits for contributions to candidates running against self-funded opponents. The present proposal mitigates the millionaire's advantage further, in that personal funds will be subject to EEC matches like other funds and flow to incumbents like other financially disadvantaged candidates. In such a case, whichever candidate wins would enjoy diminished indebtedness to private donors after the election.

The EEC's fundraising mechanism should also prove politically more palatable than public financing proposals. Simply put, it will not depend on public funding, thus avoiding the principal stumbling block of otherwise attractive clean money reforms. Nor once authorized will the plan depend on ongoing political support for funding, cycle after cycle. The rub, of course, is building the endowment to support an expensive system of subsidies.

\section{A billion here, a billion there}

That brings us to perhaps the most important obstacle to the plan: funding. Any campaign financing reform that hopes to separate money from politics will require an ambitious mechanism for fundraising that is independent of campaigns. Long the ideal of most reformers, public financing of congressional elections has long faltered because of precisely this obstacle. Citizens not being enthusiastic about tax dollars going to pay for campaigns (among other reasons), incumbent politicians have not been willing to appropriate the money.

The pragmatic reformer's question thus becomes: How might we devise a more equitable campaign finance system while avoiding the daunting political and economic costs of public financing? The proposal here is to finance the EEC matching funds program with the income on a privately funded endowment. Such an endowment would need to be substantial, to say the least, but once established, would provide a permanent, self-sustaining financing mechanism. The first question thus becomes: How large an endowment would be needed for the plan to work? What follows is a back-ofthe-paper-sack estimate, the assumptions for which are admittedly speculative, intended mainly to promote further discussion. For present purposes, I assume that, in the beginning, the plan will only apply to House general elections, then be expanded depending on its effectiveness.

The plan will take effect gradually as more districts become open in at least one election, but for purposes of illustration, I shall assume that when fully mature the EEC incentives increase by half the number of competitive seats. Given that competitiveness depends on a range of factors other than campaign financing, this would doubtless count as a resounding success. In 2004 there were 71 seats where the winning margin was less than $20 \%$. About five of these races saw rough funding equality and would not have been eligible for subsidies. Thus, 66 times 1.5 equals 99 races-for convenience, rounded up to 100 -in the steady state where a general election candidate proves eligible for EEC grants.

Second, I assume that the EEC incentives enable all qualifying, under-funded candidates to raise matchable funds at the margin up to the maximum. At the same time, I shall not assume that the matches have a depressing effect on the better-funded candidate's fundraising ability. Taken together, these two assumptions thus err toward a substantial overestimate of the total cost.

To estimate that cost, I shall work from the more readily available statistics on candidate total expenditures rather than public communication expenditures. As I note above, Ansolabahere and Gerber (1994) have calculated that candidates spend on average two to three dollars out of every five on "voter contact," the definition of which is only a little broader than the BCRA definition of communication expenditures. I'll thus assume that $40 \%$ of all candidate expenditures go to campaign communications. Without any subsidy, the average gap in expenditures in EEC-eligible races approximates the typical gap between an incumbent and a quality challenger, which in 2004 dollars 
was about $\$ 750,000$ or about $\$ 300,000$ in spendable communication dollars. Assume further that the financially advantaged candidates also average an additional $\$ 100,000$ advantage in non-party independent advertising, which in the present formula gets counted as if it were candidate advertising. Taking into account the $67 \%$ incumbent/challenger return to advertising ratio discussed above, about $\$ 270,000$ $(\$ 400,000 \times 67 \%)$ is needed to effectively equalize the two candidates' campaign advertising. Assuming that the higher quality candidate drawn into the race can, with the help of the matching incentives, net half of that sum at the margin, an average 1:1 match would generate the other $\$ 135,000$ in the form of a costless EEC grant.

In order to achieve effective parity for every eligible race qualifying for the maximum match, the EEC would thus need 100 races $x$ $\$ 135,000$ or $\$ 13.5$ million, an amount that its endowment would have to generate over two years. Earning a real rate of return of 3.5\%, compounded annually, the endowment principal would thus need about $\$ 190$ million to finance a fully implemented system for House elections. But let's assume that incumbents respond irrationally by raising more, not less, money in response to the stronger challengers, and let's assume that measurable independent electioneering is double what I've assumed. Then the cost of the system might be twice my estimate, \$380 million.

Could such an endowment be raised for an institution that promises substantial benefits to American democracy? Perhaps, if someone of, say, John McCain's stature took up the cause, soliciting EEC contributions from wealthy individuals. A George Soros, a Ted Turner, or a Ross Perot could cover it with a single check. The new system could also solicit large grants from the private foundations and good government groups that have already spent millions toward improving democratic institutions in the U.S., among them Common Cause, the Pew Charitable Trust, Congress Watch, the Center for Public Integrity, the Campaign Finance Institute, Democracy 21, and the League of Women Voters. Perhaps reform-minded individuals of lesser means, who have quit giving to campaigns because of the relative size of their (immediately consumed) gift, might also contribute to a fund whose benefits last well into the future. With reform-minded individuals and foundations urging them to do so, over time this might come to a substantial sum.

\section{RETHINKING CAMPAIGN FINANCE REFORMS}

Over the years, students and advocates of congressional campaign finance reform have offered various proposals to repair the problems of the private money system, most commonly in some form of "clean money," such as free air time or public financing of congressional campaigns. ${ }^{27}$ Before quitting the present analysis, it is worth briefly comparing their merits to the present proposal.

Public financing has the virtue of not restricting campaign spending unless the candidate voluntarily accepts restrictions as a condition of receiving public funds. And it has the potential to diminish the reach of private power into electoral and congressional politics. So too does Ackerman and Ayres' (2002) innovative proposal in Voting with Dollars, a plan in which the government would provide each voter with fifty "patriot dollars" to contribute to candidates or parties as she sees fit. Additional contributions by well-to-do individuals or organizations would still be permitted, but their impact on campaigns and hence on postelection policymaking would be inhibited by enforced anonymity, and they would be otherwise "diluted by a flood of patriot dollars" (Ackerman and Ayres 2002, 172).

Despite these virtues, both conventional public financing and voting with dollars suffer from the irony that a cynical public exhibits little support for clean money proposals. The leading scholar of congressional elections, Gary Jacobson, puts it flatly: "financing congressional campaigns with tax dollars has no effective constituency" (2006, 202). Distaste for the idea is apparent in the small fraction (about

${ }^{27}$ Common Cause has pushed some version of clean money campaign finance reform for over three decades. See < http://www.commoncause.org $>$. See also Magleby and Nelson (1990). 
1 in 9) of taxpayers who use their tax check-off option to earmark (at no cost to themselves) three dollars for public financing of presidential campaigns. The cost to taxpayers of financing House elections alone would cost several hundred million dollars in each electoral cycle, depending on the funding formula, ${ }^{28}$ and voting with dollars would cost much more. That would be real money going to elect unseemly politicians who would then only catch "Potomac fever" or practice "honest graft" after getting elected.

Even if adopted, public and legislative support for such substantial spending would need to be sustained with each new Congress in the face of perennial temptations to rescind the program and free up funds for politically more attractive appropriations. If a public financing regime did hurt incumbents, the rationalizations for putting the money to other, perhaps counterproductive purposes would doubtlessly multiply. Malbin and Gais come to just this conclusion in their study of state-level campaign finance laws:

The problem is that maintaining legislative support over the long haul requires a consensus in support of a program's basic purposes, and maintaining such a consensus requires legislators to forego the clear temptation, when they adjust a program, to use their majorities for partisan or divisive ends. This temptation is hard to resist. (Malbin and Gais 1998, 73-74.)

The present proposal, in contrast, would require only initial authorization of an EEC institution. Thereafter, no appropriations need be squeezed into budget subfunctions; no coalitions need be built; no killer amendments need be fended off. Financial support will need to be solicited, to be sure, but it's possible that this could be accomplished through the one-time commitments of a few wealthy individuals or foundations, were they to be persuaded of its merits.

A second limitation of clean money proposals, if constitutionally devised, is that they do relatively little to affect competitiveness in congressional elections. ${ }^{29}$ With most matching grant provisions, public financing provides at least as much to candidates who already enjoy a substantial fundraising advantage as to their underfunded opponents. And if public funding does not protect that advantage, better financed candidates need not participate. They can opt out if, say, the spending caps attached to public funds begin to erase their advantage. In the eleven states with public funding for gubernatorial races, Malbin and Gais (1998) found that candidates for governor chose not to participate in about a third of the cases. In two states that had public financing of state legislative races, they found that approximately a fifth of the candidates did not participate. More generally, their analysis of campaign finance laws in all 50 states revealed that while a variety of public financing regimes had been tried, "there is no evidence to support the claim that programs combining public funding with spending limits have leveled the playing field, countered the effects of incumbency, and made elections more competitive" $(1998,137)$.

Ackerman and Ayres' proposal for anonymous contributions diminishes the expected legislative value to contributors of donating large sums to incumbents. Legislators will simply not know who their contributors are, and thus contributors cannot credibly call in the debts. If a system of effective anonymity could be devised, a good deal of the interest group money extorted by well-placed incumbents would thus dry up. But it is doubtful that the challenger would somehow gain the advantage in raising private funds, as Ackerman and Ayres suggest $(2002,40)$, or significantly offset incumbents' huge advantages. Incumbents would still enjoy greater advantages in name recognition and media attention that would help them secure patriot dollars early and of-

\footnotetext{
28 See Lowenstein (1989) for an intentionally lean public financing proposal that would cost 180 million dollars in 1986 dollars, which in 2006 campaign dollars would be over twice as much.

${ }^{29}$ See Lowenstein (1989) for one exception. His proposal would channel money through political parties, who would then allocate the funds to races that had a reasonable chance of success. See also the proposal for free media vouchers by the Campaign Finance Institute (2005). The CFI's own model of the proposal's effects suggested that its effects on competitiveness would be modest, perhaps detrimental in Senate races in large states.
} 
ten, which could then be used to attract still more patriot dollars. If so, patriot dollars could turn out to be incumbent reelection coupons. In any case, the non-competitiveness of congressional elections is not a problem that voting with dollars is well-designed to address. The present proposal, in contrast, targets the problem of non-competitive elections directly, without immediately threatening the incumbents who would need to authorize it nor requiring them to provide the means to finance it.

\section{CONCLUSION}

This article has explored the idea of an Expenditure Equalizing Commission for congressional elections. If adopted and implemented, it should promote significant, beneficial consequences, first for House and later for Senate elections. Of course, the confidence one might have in that promise can only be speculative at this point, given the numerous assumptions and uncertainties neglected or set aside here. Hence, this article is perhaps best read as an instrument for vetting the idea of extra-governmental, self-regulating mechanisms for equalizing campaign expenditures.

Like the BCRA, the EEC system does not pretend to solve all of the problems associated with the current system. The financing mechanism proposed here is something of a middle ground between the status quo, which leaves candidates too much at the mercy of large, well-heeled donors, and a full-blown public financing system, which would require pubic money and cost hundreds of millions every election cycle. Other reforms, currently being debated, would enhance the effectiveness of the EEC system. One is to bring 527 organizations into the same regulatory regime as PACs and other hard money entities. A second is the McCain-Feingold-Durbin bill recently before Congress which would require radio and television broadcasters to provide free air time to candidates for political debate prior to general elections (Campaign Finance Institute 2005).

However exploratory at this point, new modes of campaign finance warrant discussion, for the stakes are high. The current system exacerbates the low competitiveness of congres- sional elections and it has significant, detrimental consequences for post-election congressional policymaking. Elected or reelected to Congress, the member brings his campaign baggage with him to his legislative office. Implicit debts or connections to donors occupy some significant space in his satchel. And in all likelihood, those donors will be needed two years hence.

This indebtedness is insidious in several ways. As noted above, it is not at all clear that campaign contributions buy votes. But if they only buy greater access to a member or to the legislative process, they have compromised the equality of political representation. Money gives extra voice to those who would make demands or pursue their interests. Even if it buys only a little access, even a little access can go a long way, depending on the group's lobbying strategy. Access often gives a group or individual or industry the opportunity to subsidize the legislative effort of busy members on issues where member and group have coincident interests (Hall and Deardorff 2006). Thus are members' priorities changed even if their positions stay the same. The ideas and interests of groups who lack the capacity to contribute get less attention and representation as a result, and the collective deliberations of Congress are less fully informed. The "appearance of corruption" - a standard made constitutionally meaningful by the Court-has not been diminished much by the BCRA. Candidates still need to depend heavily, if not primarily, on the largesse of organized outsiders who give with an eye to furthering their private interests on the inside. As long as this dependence remains, the public will rightly remain skeptical of the claim that interest groups are giving something for nothing.

\section{REFERENCES}

Ackerman, Bruce and Ian Ayres. 2002. Voting with Dollars, New Haven: Yale University Press.

Ansolabehere, Stephen, John de Figueiredo, and James Snyder, Jr. 2003. 'Why Is There So Little Money in U.S. Politics?" Journal of Economic Perspectives 17 (Winter) 105-130.

Ansolabehere, Stephen and Alan Gerber. 1994. "The Mismeasure of Campaign Spending: Evidence from the 1990 U.S. House Elections." Journal of Politics 56 (November): 1106-18. 
Birnbaum, Jeffrey H. 1992. The Lobbyists: How Influence Peddlers Get Their Way in Washington. New York: Times Books.

Boatright, Robert G., Micahel J. Malbin, Mark J. Rozell, and Clyde Wilcox. 2006. "Interest Groups and Advocacy Organizations after BCRA." In Michael J. Malbin, ed., The Election After Reform. Lanham, MD: Rowman \& Littlefield Publishers.

Box-Steffensmeier, Janet M. 1996. "A Dynamic Analysis of the Role of War Chests in Campaign Strategy." American Journal of Political Science 2 (May): 342-371.

Brader, Ted. 2005. Campaigning for Hearts and Minds. Chicago: University of Chicago Press.

Briffault, Richard. 2002. "McConnell v. FEC and the Transformation of Campaign Finance Law." Election Law Lournal 3(2): 147-176.

Briffault, Richard. 2005. "The 527 Problem . . . and the Buckley Problem." George Washington Law Review, 73: 949.

Campaign Finance Institute. 2002. < http://www.cfinst. org/studies/vital>.

Campaign Finance Institute. 2005. "Radio-TV Vouchers for Congressional Races Likely to Increase Competitiveness and Promote Public Debate." < http://www. cfinst.org >. July 14, 2005.

Campaign Finance Institute Task Force. 2003. “Participation, Competition, Engagement: Reviving And Improving Public Funding For Presidential Nomination Politics." < http://www.cfinst.org/presidential/report>.

Coleman, John J. and Paul F. Manna. 2000. "Congressional Campaign Spending and the Quality of Democracy." Journal of Politics 62 (August): 757-789.

Cooper, Joseph, ed. 1999. Congress and the Decline in Public Trust. Boulder, CO: Westview Press.

Corrado, Anthony. 2003. "A History of Federal Campaign Finance Law." In Thomas Mann, ed., Campaign Finance Sourcebook, 2nd Ed. Washington, D.C.: Brookings Institution Press.

Epstein, David and Peter Zemsky. 1995. “Money Talks: Preempting Quality Challengers in Congressional Elections." American Political Science Review 89 (May): 295-308.

Evans, Diana. 1996. “Before the Roll Call: Interest Group Lobbying and Public Policy Outcomes in House Committees." Political Research Quarterly 49 (June): 287-304.

Franz, Michael M., Joel Rivlen, and Kenneth Goldstein. 2006. "Much More of the Same: Television Advertising Pre-and Post-BCRA." In Michael J. Malbin, ed., The Election After Reform. Lanham, MD: Rowman \& Littlefield Publishers.

Gais, Thomas. 1996. Improper Influence: Campaign Finance Law, Political Interest Groups, and the Problem of Equality. Ann Arbor: University of Michigan Press.

Goldenberg, Edie N., Michael W. Trauggott, and Frank R. Baumgartner. 1986. "Preemptive and Reactive Spending in U.S. House Races." Political Behavior 8(1):3-20.

Goodliffe, Jay. 2002. "The Effect of War Chests on Challenger Entry in U.S. House Elections." American Journal of Political Science 45 (October): 830-44.

Grier, Kevin B. and Michael C. Munger. 1993. "Compar- ing Interest Group PAC Contributions to House and Senate Incumbents, 1980-86." Journal of Politics 3 (August): 615-643.

Hall, Richard L. and Alan V. Deardorff. 2006. "Lobbying as Legislative Subsidy." American Political Science Review 100 (February): 69-84.

Hall, Richard L. and Frank Wayman. 1990. "Buying Time: Moneyed Interests and the Mobilization of Bias in Congressional Committees." American Political Science Review 84 (November): 797-920.

Hojnacki, Marie and David Kimball. 1998. “Organized Interests and the Decisions of Whom to Lobby in Congress." American Political Science Review 92 (December): 775-790.

Jackson, Brooks. 1990. Honest Graft. Big Money and the American Political Process. New York: Knopf.

Jacobson, Gary. 1978. "The Effects of Campaign Spending on Congressional Elections." American Political Science Review 72 (September): 769-83.

Jacobson, Gary. 2003. The Politics of Congressional Elections, Sixth Edition. New York: Longman.

Jacobson, Gary C. 2006. "The First Congressional Elections After BCRA." In Michael J. Malbin, ed., The Election After Reform. Lanham, MD: Rowman \& Littlefield Publishers.

Krasno, Jonathan K., Donald P. Green, and Jonathan A. Cowden. 1994. "The Dynamics of Campaign Fundraising in House Elections." Journal of Politics 56 (May): 459-74.

Langbein, Laura I. 1986. "Money and Access: Some Empirical Evidence." Journal of Politics 48 (November): 1052-62.

Langbein, Laura and Mark Lotwis. 1986. "The Political Efficacy of Lobbying and Money: Gun Control in the U.S. House." Legislative Studies Quarterly 15 (3): 413-40.

Levitt, Steven D. and Catherine D. Wolfram. 1997. "Decomposing the Sources of Incumbency Advantage in the U.S. House." Legislative Studies Quarterly 22: 45-60.

Lowenstein, Daniel H. 1989. "On Campaign Finance Reform: The Root of All Evil is Deeply Rooted." Hoefstra Law Review 18 (Fall): 1989.

Magleby, David B. and Candace J. Nelson. 1990. The Money Chase: Congressional Campaign Finance Reform. Washington, DC: Brookings Institution Press.

Makinson, Larry. 2003. Speaking Freely: Washington Insiders Talk About Money in Politics, 2nd Edition. Washington: Center for Responsive Politics.

Malbin, Michael J., ed. 2006. The Election After Reform. Lanham, MD: Rowman \& Littlefield Publishers.

Malbin, Michael J. and Thomas L. Gais. 1998. The Day After Reform: Sobering Campaign Finance Lessons from the American States. Albany, NY: Rockefeller Institute Press.

Mann, Thomas E. 2005. "The FEC: Administering and Enforcing Campaign Finance Law." In Anthony Corrado et al., eds. The New Campaign Finance Sourcebook, 2nd Ed. Washington, D.C.: Brookings Institution Press.

Mann, Thomas E. and Norman J. Ornstein. 2002. "Myths and Realities about the Bipartisan Campaign Reform 
Act of 2002." On the Docket. Washington: Democracy 21. May 7.

McCain, John. 2004. "Reclaiming our Democracy: The Way Forward." Election Law Journal 3 (2): 115-121.

McConnell v. Federal Election Commission, 540 U.S. 93 (2003).

Ortiz, Daniel R. 2005. "The First Amendment and the Limits of Campaign Finance Reform." In Anthony Corrrado et al., eds., The New Campaign Finance Sourcebook, 2nd Ed. Washington, D.C.: Brookings Institution Press.

Randall v. Sorrell, 126 S. Ct. 2479 (2006).

Snyder, James Jr. 1992. "Long-Term Investing in Politicians, or Give Early, Give Often." Journal of Law and Economics 35 (April): 15-43.

Stern, Phillip. 1998. The Best Congress Money Can Buy. Pantheon.

Stone, Walter J., L. Sandy Maisel, and Cherie D. Maestas. 2004. "Quality Counts: Extending the Strategic Politician Model of Incumbent Deterrence." American Journal of Political Science 48: 479-495.

Stratmann, Thomas. 2004. "How Prices Matter in Politics: The Returns to Campaign Advertising." Unpublished ms. <http://economics.uchicago.edu/download/ campad_4-19-04.pdf $>$.

Stratmann, Thomas. 2005. "Money in Politics: A (Partial) Review of the Literature." Public Choice 124: 135-156.

Tripathi, Mickey, Stephen Ansolabehere, and James M. Snyder. 2002. "Are PAC Contributions and Lobbying Linked? New Evidence from the 1995 Lobbying Disclosure Act." Business and Politics 4: 131-155.
VandeHei, Jim and Jeffrey H. Birnbaum. 2004. "Kerry Issues List Detailing Contacts With Lobbyists," Washington Post, April 22, p. 1.

Weissman, Stephen R. and Ruth Hassan. 2006. "BCRA and 527 Groups." In Michael J. Malbin, ed., The Election After Reform. Lanham, MD: Rowman \& Littlefield Publishers.

Weissman, Stephen R. and Kara D. Ryan. 2006. "Non Profit Interest Groups' Election Activities and Federal Campaign Finance Policy: A Working Paper." < http:// www.cfinst.org $>$.

West, Darrell M.and Burdett A. Loomis. 1999. The Sound of Money. New York: WW Norton.

Wright, John R. 1990. "Contributions, Lobbying, and Committee Voting in the House of Representatives." American Political Science Review 84 (June): 417-438.

Wright, John R. 1996. Interest Groups and Congress: Lobbying, Contributions, and Influence, Needham Heights, MA: Allyn and Bacon.

Address reprint requests to: Richard L. Hall

Ford School of Public Policy 4130 Weill Hall University of Michigan Ann Arbor, MI 48109

E-mail: rlhall@umich.edu 